\title{
PATIENT-CENTERED CARE: HOW DO PATIENTS PERCEIVE ITS IMPLEMENTATION?
}

\author{
Dian Kusuma Wati',2), Eti Poncorini Pamungkasari'1), \\ Ari Natalia Probandari1) \\ 1)Masters Program in Family Medicine, Universitas Sebelas Maret \\ ${ }^{2)}$ Faculty of Medicine, Universitas Islam Malang
}

\begin{abstract}
Background: Modern healthcare systems are rapidly changing to adopt a more patientcentred approach to care. Patient-centered care (PCC) is a main determinant of care quality. Patient-centered care has many associated benefits, and has been shown to improve health communication, increase patient self-care and adherence to treatment regimens, improve continuity of care, and increase patient satisfaction. This study aimed to analyze patient's perception in PCC implementation.

Subjects and Method: This was a qualitative study conducted at a general practitioner clinic in Malang. A sample of 6 patients was selected for this study. The theme of this study was patient's perception in PCC implementation. The data were collected using indepth interview and analyzed by content analysis.

Results: Of the 6 informants, 4 informants reported that they were informed and given the opportunity to choose health service, but the other 2 informants reported that they were not informed and were not given the opportunity to choose health service.

Conclusion: Most patients at general practitioner clinic get information and are involved in choosing health service.
\end{abstract}

Keywords: patient-centered care, perception, patient

\section{Correspondence:}

Dian Kusuma Wati. Masters Program in Family Medical, Universitas Sebelas Maret. Jl. Ir. Sutami No. 36A, Kentingan, Surakarta 57126, Central Java.

Email: diankusumawati@student.uns.ac.id.

The 5th International Conference on Public Health

Best Western Premier Hotel, Solo, Indonesia, February 13-14, 2019 | 611

https://doi.org/10.26911/theicph.2019.05.10 